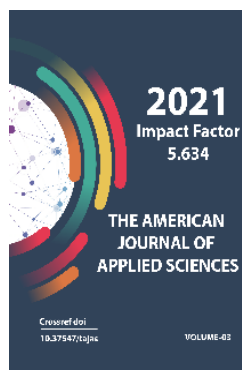

\title{
Developing Creative Activities In Technology Lessons: Using Some New Interactive Methods
}

Ismoiljon Karimov

Associate Professor, Department Of Technological Education, Candidate Of Pedagogical Sciences At Kokand State Pedagogical University, Ferghana, Republic Of Uzbekistan

Journal Website:

http://usajournalshub.c om/index,php/tajas

Copyright: Original content from this work may be used under the terms of the creative commons attributes 4.0 licence.

\section{ABSTRACT}

At the time being, special attention is paid to teaching students a creative thinking in technical science in general secondary schools. This can be seen in the example of curricula, timetables and textbooks published on this subject. In particular, in the curriculum and textbooks for grades 8-9 there is a section "Technology for preparing creative projects", which helps how to perform creative work.

It should be noted that teaching pupils and students to think and work creatively is not an easy task. To do this, it is necessary periodically to inform them about creative works, methods and stages of their implementation. However, using some of the interactive methods in practice is also effective. Regarding this, to use certain interactive methods, we have created and improved several new interactive methods and applied them into a practice. We would like to recommend several interactive methods aimed at organizing and developing students' creative activities in technology classes which are given below.

\section{KEYWORDS}

Implementation, morphological analysis, designations, learning phase, teaching phase. 


\section{INTRODUCTION}

1. Method for determining the future view of the object according to available data. This is useful for figuring out how an object or mechanism will look like in the future, and on what principles they will work and be used, based on historical and current data. For example, you can use the following table (the method is proposed by the author):

\begin{tabular}{|c|c|c|c|}
\hline Item & $\begin{array}{l}\text { Existed in the past } \\
\text { (historical info) }\end{array}$ & Existing now & $\begin{array}{c}\text { Future } \\
\text { expectation }\end{array}$ \\
\hline Pen & $\begin{array}{l}\text { Straw, feather, ink, } \\
\text { pens }\end{array}$ & Ballpoint pens & Electronic pens \\
\hline Watch & mechanical, electronical & $\begin{array}{c}\text { mechanical, electronical, } \\
\text { smart watches }\end{array}$ & $\begin{array}{l}\text { Smart watches, } \\
\text { etc. }\end{array}$ \\
\hline TV set & With lamps & With micro schemes, LCD & $\begin{array}{c}\text { Three } \\
\text { dimensional, } \\
\text { without electric, } \\
\text { air converting } \\
\text { powered }\end{array}$ \\
\hline Computer monitor & Electronic beam & $\begin{array}{l}\text { Electronic beam, plasma, } \\
\text { LCD }\end{array}$ & $\begin{array}{c}\text { Three } \\
\text { dimensional, } \\
\text { without electric, } \\
\text { air converting } \\
\text { powered }\end{array}$ \\
\hline etc. & $\cdots$ & ... & $\ldots$ \\
\hline
\end{tabular}

2. Morphological table in solving creative problems. Nowadays, there are many methods of the theory of inventive problem solving, such as the algorithm for solving inventive problems and brainstorming, morphological analysis and synthesis, synectics, functional analysis.

In particular, the method of morphological analysis and synthesis (a short morphological table) is effective in organizing the creative works corresponding to the age and cognitive characteristics of students as well as in choosing an suitable form for students. It is very useful when comparing with other appearances (this is improved by the author based on the method of morphological box). So how can this method be used in technology lessons?

Let's say we are given the task of making wellshaped stand for telephone set can be put on (or other object). To solve this problem, the work of students can be organized in the following stages: 
The American Journal of Applied sciences (ISSN - 2689-0992)

Published: April 30, 2021 | Pages: 187-198

Step 1. Analysis of the assignment state. It is well known that the telephone is an important means of communication that keeps us close together and makes easier to get in touch each other. For the convenience of using telephone devices and extending their service life, various extensions are used. Figure 1 shows three types of such stands.
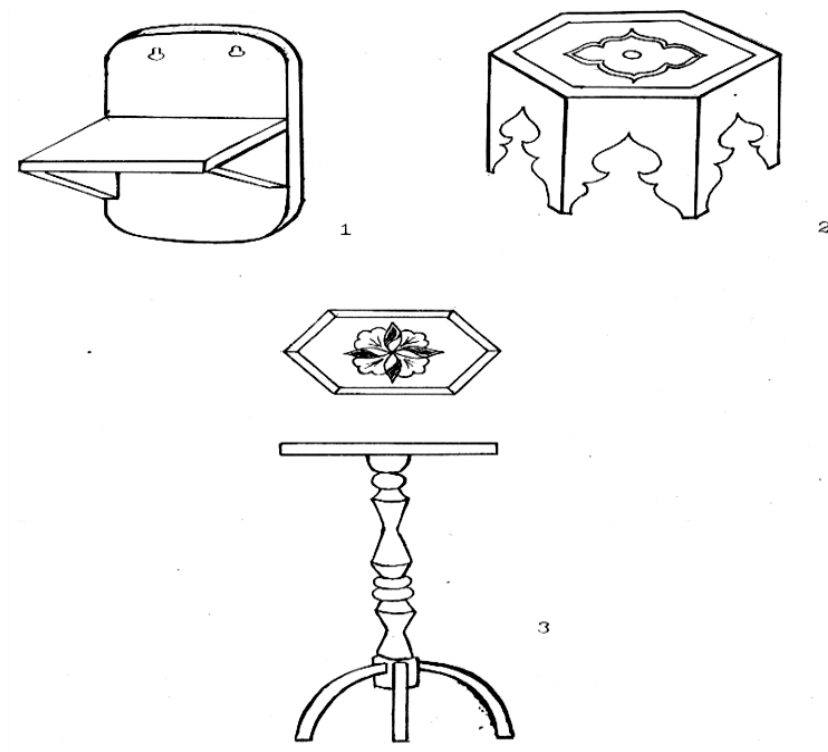

Figure 1. Phone stand:

1 - wall-fixed base; 2 - national small course; 3 - shaped table.

The first of them, namely the wall-fixed stand is much more convenient to use. But according to the assignment, we are asked to prepare a phone stand in the form of a stool. The second stand in the form of a national chair is good. But for doing this takes a lot of time, material and higher skills. In addition, the most important thing is that most students in grades 5, 6 and 7 do not know how to make such chairs beautifully and gracefully.

Therefore, in our opinion, the solution that satisfies the condition of the problem is the preparation of the stand in Figure 3. This is due to the fact that in addition to working on a lathe on wood, indicated in the curriculum, you can also perform work related to folk art, for example, painting and carving. Besides, the structure of this stand is not so complicated. It consists of a top board, a column (foundation) and legs. This analysis is called morphological analysis.

In order to organize the creative work of students the teacher proposes them to choose a table that looks different from the one shown 
The American Journal of Applied sciences (ISSN - 2689-0992)

in the picture that is each child has a table that he likes. To facilitate the work of students a special morphological table has been created. The table serves as the main tool in solving the problem. Therefore, special attention should

Table 1

MORPHOLOGICAL TABLE FOR MAKING A FIGURED TABLE TO PLACE be paid to the developing and using such tables (stools). These ideas are reflected in Table 1.

\begin{tabular}{|c|c|c|c|c|c|c|}
\hline \multirow[t]{2}{*}{ Parts of the product } & \multicolumn{6}{|c|}{ Alternative views } \\
\hline & 1 & 2 & 3 & 4 & 5 & 6 \\
\hline \multicolumn{7}{|c|}{ I. Top panel } \\
\hline 1. Material types & board & plastic & metal & plywood & ceramics & ... \\
\hline 2. Forms (shapes) & round & oval & 5-faced & 6-faced & 8-faced & $\ldots$ \\
\hline 3. Decoration & $\begin{array}{l}\text { without } \\
\text { image }\end{array}$ & with image & no pattern & $\begin{array}{l}\text { carved } \\
\text { pattern }\end{array}$ & $\begin{array}{l}\text { instructional } \\
\text { (inlaid) }\end{array}$ & $\ldots$ \\
\hline \multicolumn{7}{|c|}{ II. Column } \\
\hline 1. Material types & wood & plastic & org. glass & metal & $\begin{array}{c}\text { ganch } \\
\text { (uzbek national } \\
\text { carving) }\end{array}$ & $\cdots$ \\
\hline 2. Forms (shapes) & round & 3-facets & 4-facets & 6-facets & 8 -facets & $\ldots$ \\
\hline 3. Decoration & $\begin{array}{l}\text { shapeless, } \\
\text { smooth }\end{array}$ & $\begin{array}{l}\text { Shaped, } \\
\text { (formed) }\end{array}$ & $\begin{array}{l}\text { burned } \\
\text { pattern }\end{array}$ & $\begin{array}{l}\text { carved } \\
\text { pattern }\end{array}$ & inlaid & $\ldots$ \\
\hline \multicolumn{7}{|c|}{ III. Legs } \\
\hline 1. Material types & wood & plastic & metal & org. glass & plywood & \\
\hline 2. Forms (shapes) & $\begin{array}{l}\text { round, } \\
\text { arched }\end{array}$ & round straight & $\begin{array}{c}\text { 3-cro-lobular } \\
\text { straight }\end{array}$ & $\begin{array}{l}\text { 4-cro- } \\
\text { lobular } \\
\text { straight }\end{array}$ & $\begin{array}{c}\text { polygonal } \\
\text { straight lines }\end{array}$ & $\cdots$ \\
\hline
\end{tabular}


The American Journal of Applied sciences (ISSN - 2689-0992)

Published: April 30, 2021 | Pages: 187-198

\begin{tabular}{|c|c|c|c|c|c|c|}
\hline & & & & & & \\
\hline 3. Decoration & no picture & formed & $\begin{array}{c}\text { carved } \\
\text { pattern }\end{array}$ & $\ldots$ & $\ldots$ &.. \\
\hline 4. Number of legs & 3 & 4 & 5 & 6 & 8 & $\ldots$ \\
\hline
\end{tabular}

\section{Additional functions}

\begin{tabular}{|c|c|c|c|c|c|c|}
\hline To put flowers & $\begin{array}{c}\text { to put } \\
\text { notepads }\end{array}$ & $\begin{array}{c}\text { to lay down } \\
\text { book }\end{array}$ & to put chess & etc. & & \\
\hline
\end{tabular}

Parts of the table: board, base and legs - are recorded in separate cells in the form of a column. To clarify the content of the issue, the words "material, shape, decoration" are written in the squares with details. After that, the corresponding information is recorded before each of them in alternative representations (table 1). Morphological table \#1 has the following structure and contains information for developing of a decorative table. It should be considered that the described table may not only consist of these views, but may also have a broader or narrower meaning. It depends on the structure of the elements and the skill of the compiler.

Step 2. Design of the table. After the table is filled with the necessary information (or it can be a prepared in advance) students are asked to choose one in the form they like. In this case, the data pertaining to the parts of the table are represented by numbers marked in the vertical and lateral directions respectively. In this case only one view is selected for the work related to each part. That is, the synthesis work is done. For example, the table shown in Figure
\#1 can be selected or defined as follows: I: 1-1; 2-4; 3-2. II: 1-1; 2-1;3-2. III: 1-1; 2-1;3-1; 4-4. IV: $1-2$.

\section{These designations are read as follows:}

(I) Board: material (1) - board (1); shape (2) hexagonal (4); decoration (3) - drawing (2).

(II) Column - base: material (1) - wood (1); shape

(2) - round (1); decoration (3) - shaped (2).

(III) Legs: material (1) - wood (1); shape (2) arched (1); decoration (3) - no pattern (1); number (4) - four (2).

An additional function (IV) is that the table is designed to hold a laptop and a pen in addition to a telephone set (1-4).

Step 3. Preparing the table. After the students choose a table for the telephone set with a shape they prefer they proceed to make it. As we see above, this process is also consisted of several stages according to which table shape 
is selected. In general, the creative activity of students can be summarized as follows:

1. Determination of the dimensions of the stand parts and corresponding proportions:

2. Selection of materials for stand parts.

3. Select the necessary instruments and devices and set up for work.

4. Planning and execution of processing of stand parts (sawing table parts to the required size, grinding, artistic processing drawing, pattern making or carving, varnishing or painting, etc.).

5. Assembly and decoration of stand parts (grinding, varnishing, painting some parts and places of the table).

6. Check the stand. Analysis of the design and the work done - elimination of its shortcomings by improving the structure, finding ways to expand the scope of services.
This assignment can be performed by students in grades 6-7 in technology lessons or extracurricular activities. The use of such morphological tables allows students to save time, broadens their thinking, improves their creative skills according to an exact knowledge, a scientific basis through observation and helps to learn problem solving in various ways.

Such tables are especially useful in organizing and conducting creative work of students in grades 5-7. Besides they can be compiled based on the preparation of various simpler subjects, drawing them on large sheets of paper, writing them down and using them in the classes in accordance with the topics studied.

It is worth developing such kind of morphological tables simply at first. Tables \#2 and 3 are designed for this purpose. The rest of the tables can also be used to organize independent creative works of students. 
Table \# 2

MORPHOLOGICAL TABLE FOR CONSTRUCTING A STAND, INTENDED FOR PLACING A TELEPHONE SET (SIMPLIFIED VIEW)

\begin{tabular}{|c|c|c|c|c|c|c|c|c|c|c|}
\hline PARTS OF TH & E PRODUCT & & & & & & & & & \\
\hline PANEL & & & COLUMN & & & LEGS & & & & \\
\hline & & & & & & shape & & um & be & \\
\hline I & $a$ & $b$ & II & $a$ & $b$ & III & $a$ & $b$ & C & c \\
\hline 1) Round & with image & $\begin{array}{l}\text { without } \\
\text { image }\end{array}$ & round & $\begin{array}{l}\text { no pattern } \\
\text { (shapeless) }\end{array}$ & $\begin{array}{l}\text { with } \\
\text { pattern } \\
\text { (shaped) }\end{array}$ & round & 3 & 4 & 5 & 6 \\
\hline 2) Oval faced & with image & $\begin{array}{l}\text { without } \\
\text { image }\end{array}$ & 3 facets & $\begin{array}{l}\text { no pattern } \\
\text { (shapeless) }\end{array}$ & $\begin{array}{l}\text { with } \\
\text { pattern } \\
\text { (shaped) }\end{array}$ & 3 facets & 3 & 4 & 5 & $\epsilon$ \\
\hline 3) 3 facets & with image & $\begin{array}{l}\text { without } \\
\text { image }\end{array}$ & 4 facets & $\begin{array}{l}\text { no pattern } \\
\text { (shapeless) }\end{array}$ & $\begin{array}{l}\text { with } \\
\text { pattern } \\
\text { (shaped) }\end{array}$ & 4 facets & 3 & 4 & 5 & 6 \\
\hline 4) 3 facets & with image & $\begin{array}{l}\text { without } \\
\text { image }\end{array}$ & 5 facets & $\begin{array}{l}\text { no pattern } \\
\text { (shapeless) }\end{array}$ & $\begin{array}{l}\text { with } \\
\text { pattern } \\
\text { (shaped) }\end{array}$ & 5 facets & 3 & 4 & 5 & ( \\
\hline 5) 5 facets & with image & $\begin{array}{l}\text { without } \\
\text { image }\end{array}$ & 6 facets & $\begin{array}{l}\text { no pattern } \\
\text { (shapeless) }\end{array}$ & $\begin{array}{l}\text { with } \\
\text { pattern } \\
\text { (shaped) }\end{array}$ & 6 facets & 3 & 4 & 5 & ( \\
\hline 6) 6 facets & with image & $\begin{array}{l}\text { without } \\
\text { image }\end{array}$ & 8 facets & $\begin{array}{l}\text { no pattern } \\
\text { (shapeless) }\end{array}$ & $\begin{array}{l}\text { with } \\
\text { pattern } \\
\text { (shaped) }\end{array}$ & 8 facets & 3 & 4 & 5 & ( \\
\hline$\cdots$ & $\cdots$ & $\cdots$ & $\cdots$ & $\cdots$ & $\cdots$ & $\cdots$ & & & & \\
\hline
\end{tabular}


The American Journal of Applied sciences (ISSN - 2689-0992)

Published: April 30, 2021 | Pages: 187-198

Table \# 3

MORPHOLOGICAL TABLE FOR MAKING A CUTTING BOARD FOR VEGETABLES

\begin{tabular}{|c|c|c|c|c|c|}
\hline \multirow[t]{2}{*}{ Parts of products } & \multicolumn{5}{|c|}{ Alternative variants } \\
\hline & 1 & 2 & 3 & 4 & \\
\hline $\begin{array}{l}\text { I. Board: } \\
\text { 1. Material type }\end{array}$ & wood & plastic & org.glass & metal & eramics \\
\hline 2. Form & round & oval & 3 facets & 4 facets & $\begin{array}{l}\text { rhombus- } \\
\text { shaped }\end{array}$ \\
\hline 3. Decoration & with image & without image & $\begin{array}{l}\text { carved } \\
\text { pattern }\end{array}$ & inlaid & $\begin{array}{l}\text { pattern } \\
\text { burned }\end{array}$ \\
\hline $\begin{array}{l}\text { II. Additional } \\
\text { functios: }\end{array}$ & $\begin{array}{l}\text { For the the } \\
\text { supply of } \\
\text { hot meals }\end{array}$ & $\begin{array}{l}\text { to supply } \\
\text { other things }\end{array}$ & $\begin{array}{l}\text { to decorate } \\
\text { the room }\end{array}$ & etc. & etc. \\
\hline
\end{tabular}


The American Journal of Applied sciences

Table \# 4

MORPHOLOGICAL TABLE FOR MAKING A KNIFE FOR CUTTING PRODUCTS

\begin{tabular}{|c|c|c|c|c|c|}
\hline \multirow[t]{2}{*}{ Parts of products } & \multicolumn{5}{|c|}{ Alternative variants } \\
\hline & 1 & 2 & 3 & 4 & 5 \\
\hline \multicolumn{6}{|l|}{ I. Blade } \\
\hline 1. Material & metal & plastic & stone & bone & $\begin{array}{l}\text { Electronic } \\
\text { beam }\end{array}$ \\
\hline 2. Form & straight & long, covered & $\begin{array}{l}\text { round, } \\
\text { toothed }\end{array}$ & $\begin{array}{l}\text { blades on } \\
\text { both sides }\end{array}$ & straight short \\
\hline 3. Decoration & $\begin{array}{l}\text { without } \\
\text { image }\end{array}$ & With image & $\begin{array}{l}\text { with an } \\
\text { inscription }\end{array}$ & $\begin{array}{l}\text { without an } \\
\text { inscription }\end{array}$ & $\ldots$ \\
\hline \multicolumn{6}{|l|}{ II. Handle } \\
\hline 1. Material & wood & plastic & org.glass & bone & metal \\
\hline 2. Form & straight & With limiter & $\begin{array}{l}\text { place for } \\
\text { fingers }\end{array}$ & $\ldots$ & $\cdots$ \\
\hline 3. Decoration & with image & without image & $\begin{array}{l}\text { with an } \\
\text { inscription }\end{array}$ & $\begin{array}{l}\text { without an } \\
\text { inscription }\end{array}$ & inlaid \\
\hline \multicolumn{6}{|l|}{ III. Storage } \\
\hline & with case & without case & suspension & $\ldots$ & $\ldots$ \\
\hline $\begin{array}{l}\text { IV. Additional } \\
\text { functions: }\end{array}$ & $\begin{array}{l}\text { cutting of } \\
\text { bulky } \\
\text { things }\end{array}$ & $\begin{array}{l}\text { open up } \\
\text { bottles }\end{array}$ & $\begin{array}{l}\text { screwing } \\
\text { (unscrewing) } \\
\text { screws }\end{array}$ & $\begin{array}{l}\text { Open the } \\
\text { locks }\end{array}$ & Other functions \\
\hline
\end{tabular}


The American Journal of Applied sciences

Table \# 5

MORPHOLOGICAL TABLE FOR MAKING A CHALK-BOARD

\begin{tabular}{|c|c|c|c|c|c|}
\hline \multirow{2}{*}{$\begin{array}{l}\text { Parts of } \\
\text { products }\end{array}$} & \multicolumn{5}{|c|}{ Alternative variants } \\
\hline & 1 & 2 & 3 & 4 & 5 \\
\hline \multicolumn{6}{|l|}{ I. Panel } \\
\hline 1. Material & $\begin{array}{l}\text { wood or } \\
\text { plywood }\end{array}$ & plastic & org. glass & $\begin{array}{l}\text { plywood and } \\
\text { linoleum }\end{array}$ & linoleum \\
\hline 2. Form & round & oval shaped & $\begin{array}{l}\text { spherical } \\
\text { shaped }\end{array}$ & $\begin{array}{l}\text { square- } \\
\text { shaped }\end{array}$ & $\begin{array}{l}\text { trapezoid } \\
\text { figured }\end{array}$ \\
\hline 3. Design & $\begin{array}{l}\text { folding } \\
\text { (collapsible) }\end{array}$ & mobile & stepped & combined & $\ldots$ \\
\hline \multicolumn{6}{|c|}{ II. Mounting } \\
\hline & $\begin{array}{l}\text { using nail } \\
\text { fixing }\end{array}$ & with roller & with bracket & $\begin{array}{l}\text { using } \\
\text { magnetic } \\
\text { fields }\end{array}$ & $\cdots$ \\
\hline \multicolumn{6}{|c|}{ III. Additional Functions } \\
\hline & $\begin{array}{l}\text { placing TV- } \\
\text { set }\end{array}$ & $\begin{array}{l}\text { placing the } \\
\text { fan }\end{array}$ & $\begin{array}{l}\text { placing power } \\
\text { supply box }\end{array}$ & $\begin{array}{l}\text { placing } \\
\text { loudspeakers }\end{array}$ & $\begin{array}{l}\text { placing other } \\
\text { devices }\end{array}$ \\
\hline
\end{tabular}

So, with the help of a morphological table, students can be easily taught to solve creative assignments. Therefore, it is appropriate in a sense to call this method a transition to creativity. It should also be noted that this method is only included in our schools, it is simply used in our activities. Therefore, we hope that this method will still be repeatedly tested in experiments, will be improved and will take a firm place in technology lessons.

Using the mosaic method in teaching technology lessons. It is important to inform students about the structure and appearance of a part or an object before preparing them in a hands-on technology lesson. The role of 
drawings in explaining the structure and appearance of any detail or object is invaluable. Therefore, in technology lessons, it is appropriate to give students in advance some concepts on the subject of drawing, including such as working on drawings, sketches, technical drawings. These concepts are relevant to students and can be described as follows:

1. A clear hand-drawn image of an object is called a technical drawing. In this case, on the basis of axonometric rules, the three sides of the product are shown and the proportions between the parts of the product are preserved, the exact size or scale is not strictly observed.

2. Manually describing the appearance of an object in three planes is called a sketch. This also maintains the proportions between the parts of the product, but does not require strict adherence to the exact size or scale.

3. A clear and rigorous representation of an object in three planes based on a given size or scale using drawing tools is called a working drawing.

In this case, the technical drawing and sketch are used for the initial presentation of the object, and the working drawing is used directly in the manufacturing the product. The item information is also accompanied by a drawing of the item. These concepts can also be explained directly by the teacher through various exhibitions. In addition, the use of small group work to make students more active in the classroom has been beneficial. To apply this method, the class is divided into three groups, and the lesson is also conducted in three stages.

In phase 1, the first group of students studies a technical drawing, the second group of students studies sketches and the third group of students is asked to work on the information about the working drawing and draw the necessary images. This is called the learning phase.

In phase 2, one student is separated from each group and they come together to form new groups. Students in this newly formed group teach each other what they learned in the first phase. This is called the teaching phase.

In Phase 3, students join their groups in Phase 1 and exchange ideas about what they did and learned in Phase 2. This is called the Discussion Phase (see illustration). At the end of the lesson, the teacher reviews the completed works and gives marks. 


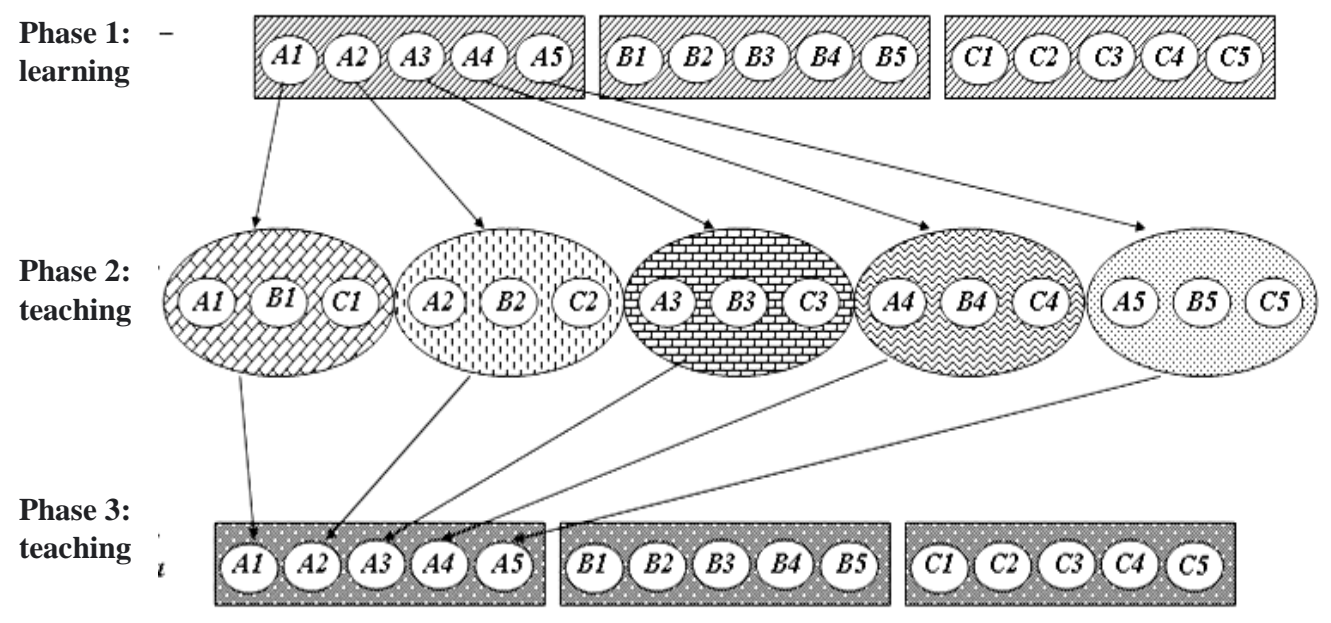

Table for working in small groups

The advantage of this method is that students will be able to study large amount of data in a short period of time. Students develop skills on independent and creative works, explaining their ideas to each other, asking questions, reminding, communicating, etc. Therefore, the use of this method is also effective when studying larger topics after some preparatory work. To make this work more fun, you can name the groups; offer the group members cards of different colors, symbols, etc. This method in the literature is also called the mosaic method due to the use of cards of different colors in the work.

In short, using of interactive methods in technology lessons described above can motivate the students to be active in the lessons by improving their creative skills.

\section{REFERENCES}

1. Calendar-thematic plan for the subject "Technology". Grades 1-9, Education
Centre of the Government, Tashkent, Uzbekistan, 2018.

2. Ismoiljon Karimov, "Advanced teaching methods in Technology lessons". Monograph, Science and Technology press, Tashkent, Uzbekistan, 2007.

3. Ismoiljon Karimov, "Using interactive methods in Technology lessons". Teacher's manual, Iskry Literatury press, Tashkent, Uzbekistan, 2020.

4. Ismoiljon Karimov, "Integrated technologies for organizing students' creative activities", Monograph, "Navruz" press, Tashkent, Uzbekistan, 2020.

5. O. Tokhirov, I. Karimov, M. Maksimova, "Technology Education" Student's book for grades 8, “Ilm-ziyo" press, Tashkent, Uzbekistan, 2019.

6. Z. Sattorova, "Technology" Student's book for grades 9, "Uzbekistan” press, Tashkent, Uzbekistan. 